residing in the province of Asia. ${ }^{1} \mathrm{He}$

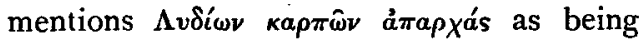
offered to Zeus. The town he wrote in was a conventus. It may have been Sardeis.

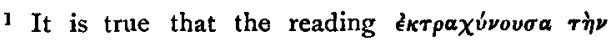
'A lav is vouched for as far as I know only by the interpolated MSS., the rest having oujoía or $\delta \sigma i a \nu$, but the mention of Lydian products is decisive.
There may have been a Zeus Akraios anywhere.

Of course this inscription does not prove that there was a Zeus Akraios at Halicarnassus, as it comes from the neighbouring Myndus, but it makes it probable that the Halicarnassian god's name was Akraios and not Ascraios.

\title{
NOTES
}

\section{A NOTE ON THE ANTIGONE OF SOPHOCLES.}

SopH. Antig. 885-888:-

$\kappa a \grave{i} \kappa a т \eta \rho \epsilon \phi \epsilon i ̄$

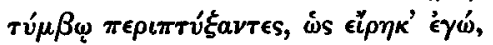

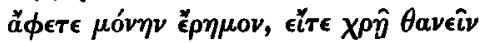

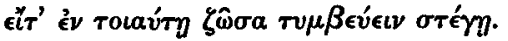

In this speech of Creon the commentators have invented an intransitive meaning for $\tau v \mu \beta \epsilon \varepsilon_{\epsilon} \iota v$, which is elsewhere transitive, and translate $\zeta_{\hat{\omega} \sigma \alpha} \tau \nu \mu \beta \epsilon \boldsymbol{v}_{\epsilon} \boldsymbol{\omega}$ by 'to live a buried life.' But in view of the fact that Antigone's crime consisted in performing the rites of burial over her brother's body, why may not $\tau v \mu \beta \varepsilon v \in \iota \nu$ be transitive with ironical signification, and the passage translated 'whether she wish to die, or, shut in such a home, to spend her life in making tombs'? This view. seems to be confirmed by the following line, where, the severity of his speech having shocked even Creon himself, he apologises with the words, "for we are not to blame in the matter of this maiden' (i.e. she had sufficient warning).

T. M. BARKER.

\section{NEWS AND COMMENTS}

Now that the two associations of headmasters have declared in favour of a reformed pronunciation of Latin, a timely publication is Dr. Postgate's How to Pronounce Latin : A Few Words to Teachers and Others (Bell, Is.), which not only tells the way to pronounce Latin, but sketches the evidence on which our knowledge rests, and discusses the arguments for and against a reform. An appendix gives three pieces of Latin verse and prose with phonetic transcript. This pamphlet should be in the hands of every teacher of Latin. Messrs Atkinson \& Pearce have also issued a cheap reprint of the Rules for Latin Pronunciation for Dent's First Latin Book, with some of the exercises in phonetic transcript (6d.).

The Board of Education has just issued a paper directing that the reformed pronunciation of Latin be adopted in schools which come under the Board. Unfortunately, the
Board still leaves a loophole of escape, in asking a school which 'prefers to adopt some other system' to 'explain it clearly' to the Board. This is, however, a long step in advance.

The death of Prof. Pelham, President of Trinity College, Oxford, removes prematurely one of the most capable workers in the Classical field. His influence was that of the teacher, the lecturer, and the administrator, rather than the student or writer, good as his work was in this department, and he had an important part in the development of newer branches of classical study at Oxford.

A correspondent draws attention to a curious error in Munro's translation of Lucretius. The passage is Book VI. line 992. Here vitro is translated by 'brass,' the cause evidently being the collocation in the text with argentum, and the similarity of sound 
with 'glass.' The error appears in both the first and the latest editions of the poet.

Professor Gilbert Davies' inaugural address on the Utility of Greek (Maclehose, University Press Glasgow) is well worth reading. The new professor of Greek dwells upon the mental training which Greek and Latin furnish in what may be called the higher regions and takes as a test the 'ability to handle abstract and general terms with understanding and accuracy'-a capacity which modern languages do not bring out in anything like the same degree. He draws attention to some advantages of Greek which are often overlooked-the instructiveness of its subtle logical development and its special importance to the student of what in this country is the much neglected study of comparative Philology. Mr. Davies is no advocate of compulsion.

It is worth remarking that the Revue de Instruction Publique en Belgique is now entering upon its fiftieth year. The aim set forth in the first number was to keep clear of party politics, and to keep in view only the intellectual interest of writers and readers. The subjects dealt with include classical and modern literature, history and geography, mathematics and science, and all other branches of secondary instruction, with the study of method. Its non-political character has been faithfully kept. To readers of the Revue it must seem strange that England has no corresponding paper.

\section{CORRESPONDENCE}

\section{HOMER AND HIS AGE.}

Mr. Allen, in his more than generous review of my Homer and His Age, says that, as to Knossian and Mycenaean archaeology 'an expert, I understand, has been retained to curse.' If Mr. Burrows be that expert, he has not, like the Archbishop in The Mort Arthur, 'done the curse in the best manner and the most orguilous,' and I thank him for correcting some misprinted numerals, while I look forward with pleasure to his promised work eon Cretan discoveries. Mr. Evans's Prehistoric Tombs at Knossos appeared too late for my purpose, and I have been unaware of its publication.

Mr. Burrows cursed not, but I think his criticism is 'perhaps a little gay.' He says that, in my book, 'Highlanders illustrate most things, and not least that the Laird of Runraurie used imported swords but homemade spades at the Battle of Killiecrankie.' I do not understand! I said nothing of the sort. If the Laird did anything at the battle, he viewed it from his drawing room window. He used no swords or spades, home-made or made in Germany; and it is NO. CLXXXIV. VOL. XXI. doubtful whether the spades which dug the shelter trenches on the hill were those of Claverhouse, or of Lord George Murray in $\mathbf{1 7 4 6 . ~ I ~ s a i d ~ n o t h i n g ~ a b o u t ~ t h e m . ~ I ~}$ said nothing at all about the Laird, except that, on his home farm, remote from any town, he had a smithy, in 1689 ; and that probably a Homeric chief, far from towns, had also his smithy; so that his ploughman and shepherd would not need 'to forge their own tools,' as Mr. Leaf supposed to be indicated in Iliad xxiii. 835. The historic Highlanders illustrate, I think, two other points of custom in my book-not 'most things.' The burden of illustrating the evolution of defensive armour is borne, successfully, I hope, by other peoples, Egyptian,mediaeval, Red Indian, and so forth. Not to know or care about military evolution, outside of the Homeric area, has been the fault, or the misfortune, of Reichel and his allies.

Is it by my own fault, or through the gaiety of Mr. Burrows that he has misunderstood me on a point of essential importance? After interesting remarks on the overlapping 